\title{
Renal artery sympathetic nerve radiofrequency denervation
}

\author{
Krzysztof Bartuś ${ }^{1}$, Jerzy Sadowski ${ }^{1}$, Bogusław Kapelak ${ }^{1}$, Radosław Litwinowicz ${ }^{1}$, Jakub Podolec ${ }^{2}$, \\ Magdalena Bartuśs ${ }^{3}$, Artur Dziewierz ${ }^{4}$, Stanisław Bartuśs ${ }^{4}$, Wojciech Zajdel², Dhanunjaya Lakkireddy ${ }^{5}$ \\ 'Department of Cardiovascular Surgery and Transplantology, Jagiellonian University, John Paul II Hospital, Krakow, Poland \\ 2Depatament of Cardiology, John Paul II Hospital, Krakow, Poland \\ ${ }^{3}$ Department of Experimental Pharmacology, Jagiellonian University, Krakow, Poland \\ ${ }^{4} 2^{\text {nd }}$ Department of Cardiology, University Hospital, Jagiellonian University, Krakow, Poland \\ ${ }^{5}$ The University of Cansas, Cansas City, United States
}

\begin{abstract}
A b stract
Background: Arterial hypertension is one of the most common chronic diseases in the western world, affecting more than $25 \%$ of the adult population.

Aim: The aim of this study was to assess changes in arterial blood pressure (BP) levels in hypertensive patients, after ablation of nerve terminals in renal arteries, using radiofrequency energy during 24 months of follow-up.

Methods: Thirty-two patients with diagnosed resistant hypertension (20 men and 12 women) underwent percutaneous catheter-based renal denervation of nerve terminals in renal artery walls. Mean BP value before ablation was [mm $\mathrm{Hg}]$ : systolic 174.92, diastolic 99.73 and pulse pressure 75.19. After procedure reduction value of BP was reported [mm $\mathrm{Hg}]: \mathrm{systolic}$ 146.78; diastolic 87.14, pulse pressure 59.64 at 24-month follow-up ( $p<0.05$ for all).

Results: $30 \%$ of patients had systolic BP $\leq 140 \mathrm{~mm} \mathrm{Hg}$, $67 \%$ had diastolic BP $\leq 90 \mathrm{~mm} \mathrm{Hg}$, and optimum BP values $\leq 140 / 90 \mathrm{~mm} \mathrm{Hg}$ were observed in $30 \%$ of patients.

Conclusions: In our cohort of patients, percutaneous renal artery ablation procedure effectively reduces systolic, diastolic $\mathrm{BP}$ and pulse pressure. No adverse events during 24 months of follow-up were noted. These results were comparable with available data from SIMPLICITY I and II trials.
\end{abstract}

Key words: hypertension, resistant hypertension, renal artery ablation

Kardiol Pol 2017; 75, 9: 899-906

\section{INTRODUCTION}

There is an increasing prevalence of arterial hypertension - nearly $26 \%$ of the world's adult population (nearly one billion people) suffer from arterial hypertension [1]. High blood pressure (BP) is the main risk factor for cardiovascular disease, renal failure, stroke, and myocardial infarction [2, 3]. Unfortunately, improvement in hypertension awareness, treatment, and control is not optimal [4]. Recent data have confirmed that only $74.9 \%$ of patients with arterial hypertension undergo treatment. In this group of patients, hypertension is well-controlled only in $52.5 \%$ of patients, suggesting that in up to a half of patients BP is uncontrolled [3].

Resistant hypertension is defined as BP that remains above the goal despite concurrent use of three antihypertensive medications (including diuretic) in optimal doses. Resistant hypertension is a severe clinical problem because it is difficult to treat and occurs in 10-12\% of hypertensive patients [5-8]. Due to that fact new therapeutic options are needed. One of the effective and safe therapeutic methods for reduction of a high BP is percutaneous renal sympathetic denervation (RN). SYMPLICITY HTN-1 and SYMPLICITY HTN-2 studies testing this method proved significant reduction in BP levels without major adverse outcomes [9-13]. However, the SYMPLICITY HTN-3 study did not confirm those findings, due to a specific patient subset attending the study (for example African American).

The aim of this study was to assess changes in arterial BP levels in hypertensive patients after ablation of nerve terminals 
Table 1. Inclusion/exclusion criteria

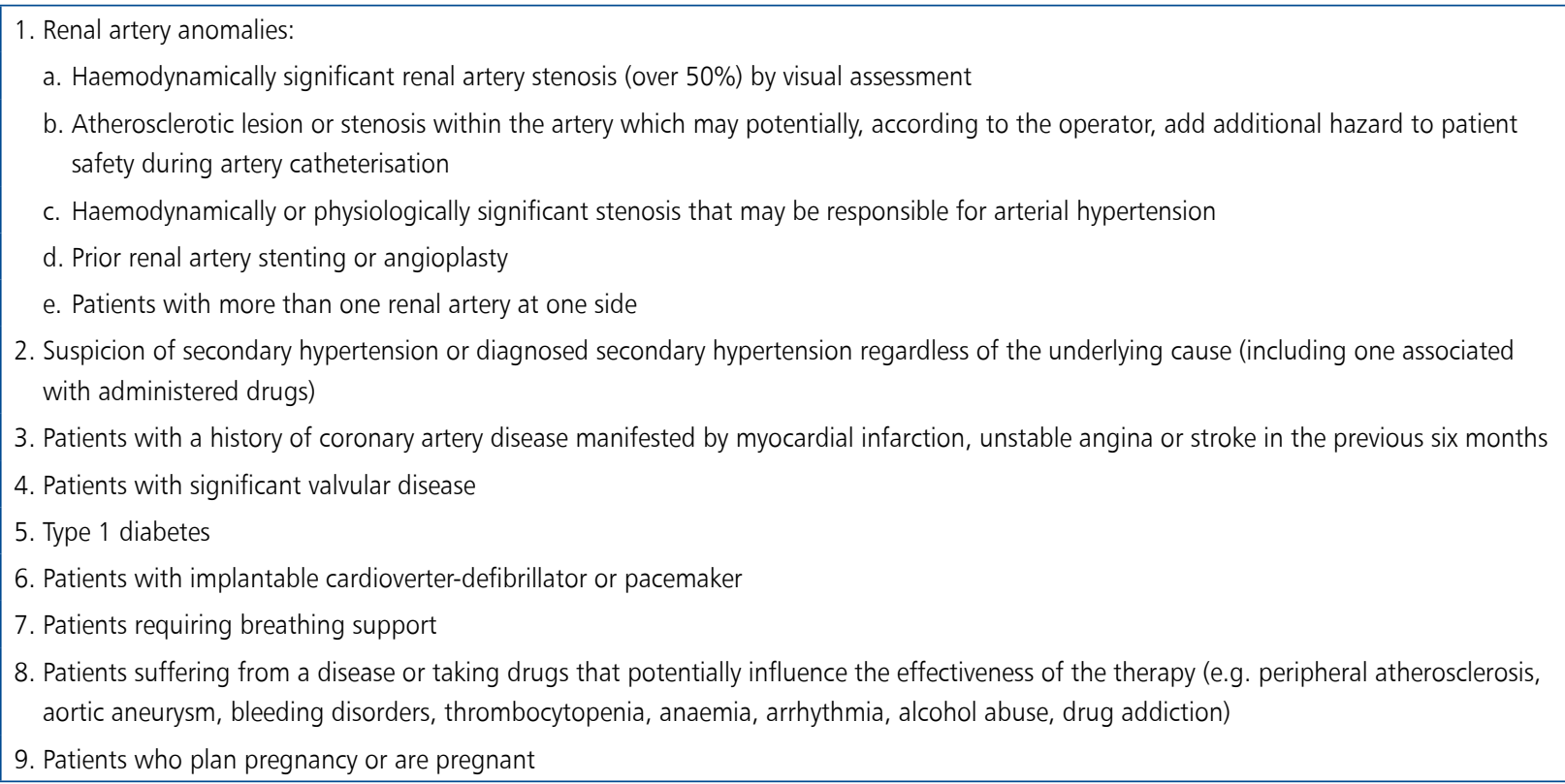

in renal arteries (denervation) as well as procedure safety in two years of follow-up of patients in the Polish population.

\section{METHODS}

All patients were the part of the HTN-1 and HTN-2 studies. Adult patients with resistant arterial hypertension, who met all inclusion/exclusion criteria (Table 1) were eligible for this study. Basically, we included patients with diagnosed arterial hypertension resistant to pharmacological treatment. The presence of resistant arterial hypertension was defined as mean brachial artery seated systolic pressure above $160 \mathrm{~mm} \mathrm{Hg}$ during out-patient department visits, despite historical compliance with at least three antihypertensive drugs (including a diuretic) in optimal doses.

Blood pressure measurement was performed in accordance with Joint National Committee 7 guidelines [14]. Measurements were performed each time by the same person, sitting, in triplicate, and then averaged.

Four weeks before renal denervation mean BP systolic value was above $160 \mathrm{~mm} \mathrm{Hg}$. Also, four weeks before procedure and during the entire study no modification of pharmacotherapy was allowed. Patient compliance with medication was strictly verified by interview and patient diary. In case of pharmacotherapy modification, patients were excluded from the follow-up analysis. Obesity was defined as waist circumference $>102 \mathrm{~cm}$ in men, $>88 \mathrm{~cm}$ in women.

The technique of renal denervation has recently been described [10-13]. After standard femoral vascular access, the SIMPLICITY catheter (Ardian Inc., USA, currently Medtronic Inc., USA) was introduced into each renal artery. During the procedure, a standard dose of unfractionated heparin was used. Six radiofrequency ablations at $8 \mathrm{~W}$ with duration up to $120 \mathrm{~s}$ each were performed in both renal arteries. Applied energy, tip temperature, and impedance were monitored by catheter system in response to a predetermined algorithm during the procedure.

Follow-up visits were performed at one, three, six, nine, 12, 18, and 24 months after the procedure. BP (systolic, diastolic, pulse pressure) measurements were performed (according to the methodology described earlier), as well as blood count, electrolytes, urea, creatinine and urine, and a physical exam including orthostatic BP measurements.

During the entire study major adverse events (death, stroke, myocardial infarction) or other outcomes associated with the procedure were monitored.

Before the study, written informed consent was obtained from all patients. The study was approved by the Institutional Bioethics Committee (two separate ethics committee approvals since the patients attended in the SYMPLICITY HTN-1 and SYMPLICITY HTN-2 studies).

\section{Statistical analysis}

For statistical analysis, we assessed continuous variables between groups, including the BP, with Student's two-sample t test. All statistics analyses were performed with Statistica (StatSoft). Statistical significance was set at $p=0.05$. All tests were two-tailed.

\section{RESULTS}

Thirty-two patients (20 men and 12 women) were included into the study. Baseline characteristics are presented in Table 2. Pre-procedure antihypertensive medications are presented in 
Table 2. Baseline characteristics

\begin{tabular}{|lc|}
\hline Patient numbers & 32 (20 men, 12 women) \\
Age (mean) [years] & $31-76(56.75)$ \\
Weight (mean) $[\mathrm{kg}]$ & $74-145(94.91)$ \\
Height (mean) $[\mathrm{cm}]$ & $159-184(169)$ \\
Body mass index (mean) $\left[\mathrm{kg} / \mathrm{m}^{2}\right]$ & $23.36-46.81(33.21)$ \\
Risk factors: & \\
Hypercholesterolaemia & $19(59 \%)$ \\
Diabetes mellitus & $11(34 \%)$ \\
Abdominal obesity (WC > 102 cm & $9(28 \%)$ \\
in men, 88 $>$ cm in women) & \\
Current smoking & $2(6 \%)$ \\
Cardiovascular disease: & \\
Heart failure (mean), NYHA grade & $1-3$ \\
Angina pectoris & $7(22 \%)$ \\
Coronary artery disease & $8(25 \%)$ \\
Myocardial infraction & $5(16 \%)$ \\
Valvular disease & $2(6 \%)$ \\
Cardiomyopathy & $2(6 \%)$ \\
Ventricular arrhythmia & $1(3 \%)$ \\
Other disease: & $2(6 \%)$ \\
Renal insufficiency & $1(3 \%)$ \\
Asthma & $1(3 \%)$ \\
Chronic obstructive pulmonary disease & $3(9 \%)$ \\
Gastric ulcer & \\
\hline
\end{tabular}

NYHA — New York Heart Association scale; WC — waist circumference

Table 3. Patients' ages ranged from 31 to 76 years (mean value 56.75 years), and body mass index ranged from 23.36 to $46.81 \mathrm{~kg} / \mathrm{m}^{2}\left(33.21 \mathrm{~kg} / \mathrm{m}^{2}\right)$. The hypertension risk factors were: hypercholesterolaemia was diagnosed in 19 patients, diabetes mellitus type 2 in 11 patients, and obesity (waist circumference $>102 \mathrm{~cm}$ in men, $>88 \mathrm{~cm}$ in women) was present in nine patients. The co-existing cardiovascular disease included: seven patients had coronary artery disease, two patients had valvular disease, two patients had cardiomyopathy, and one patient had ventricular arrhythmia. One patient had asthma, one had chronic obstructive pulmonary disease, and three patients had gastric ulcer. Only two patients were diagnosed with chronic renal insufficiency according to elevated creatinine and urea in blood serum (third grade according to classification, which means eGFR $30-59 \mathrm{~mL} / \mathrm{min} / 1.73 \mathrm{~m}^{2}$ ). No patient had symptoms of peripheral artery disease. Patients ranged by New York Heart Association classification from 1 to 3.

The mean value of three measurements of BP before ablation was: systolic from 162 to $212 \mathrm{~mm} \mathrm{Hg}$ (mean value $174.92 \mathrm{~mm} \mathrm{Hg}$ ), diastolic from 82 to $121 \mathrm{~mm} \mathrm{Hg}$ (mean value $99.7 \mathrm{~mm} \mathrm{Hg}$ ), pulse pressure from 54 to $100 \mathrm{~mm} \mathrm{Hg}$
Table 3. Pre-procedure antihypertensive medications

\begin{tabular}{|c|c|c|}
\hline Medications & $\mathbf{N}$ & $\%$ \\
\hline Beta-blockers: & 25 & $81 \%$ \\
\hline acebutolol & 1 & $3 \%$ \\
\hline betaxolol & 10 & $32 \%$ \\
\hline bisoprolol & 10 & $32 \%$ \\
\hline carvedilol & 1 & $3 \%$ \\
\hline metoprolol & 1 & $3 \%$ \\
\hline nebivolol & 1 & $3 \%$ \\
\hline sotalol & 1 & $3 \%$ \\
\hline ACEl: & 19 & $61 \%$ \\
\hline captopril & 3 & $10 \%$ \\
\hline lisinopril & 1 & $3 \%$ \\
\hline cilazapril & 1 & $3 \%$ \\
\hline enalapril & 2 & $6 \%$ \\
\hline perindopril & 1 & $3 \%$ \\
\hline quinapril & 6 & $19 \%$ \\
\hline ramipril & 4 & $13 \%$ \\
\hline trandolapril & 1 & $3 \%$ \\
\hline ARB: & 19 & $61 \%$ \\
\hline candesartan & 10 & $32 \%$ \\
\hline losartan & 2 & $6 \%$ \\
\hline telmisartan & 3 & $10 \%$ \\
\hline valsartan & 4 & $13 \%$ \\
\hline amlodipine & 10 & $32 \%$ \\
\hline doxazosin & 3 & $10 \%$ \\
\hline clonidine & 1 & $3 \%$ \\
\hline rilmenidine & 2 & $6 \%$ \\
\hline nitrendipine & 12 & $39 \%$ \\
\hline dilitazem & 3 & $10 \%$ \\
\hline Diuretics: & 46 & - \\
\hline chlortalidone & 4 & $13 \%$ \\
\hline spironolactone & 13 & $42 \%$ \\
\hline furosemide & 11 & $35 \%$ \\
\hline torasemide & 7 & $23 \%$ \\
\hline hydrochlorothiazide & 5 & $16 \%$ \\
\hline indapamide & 4 & $13 \%$ \\
\hline amiloride & 2 & $6 \%$ \\
\hline
\end{tabular}

ACEI — angiotensin-converting-enzyme inhibitors; ARB — angiotensin II receptor antagonists; beta-blockers — beta adrenergic receptor antagonists

(mean value $75.2 \mathrm{~mm} \mathrm{Hg}$ ). The heart rate ranged from 60 to 98 bpm (mean value 72.3 bpm) (Table 2).

\section{Periprocedural}

According to the protocol, six radiofrequency ablations at $8 \mathrm{~W}$ lasting up to $120 \mathrm{~s}$ each were performed in both renal 


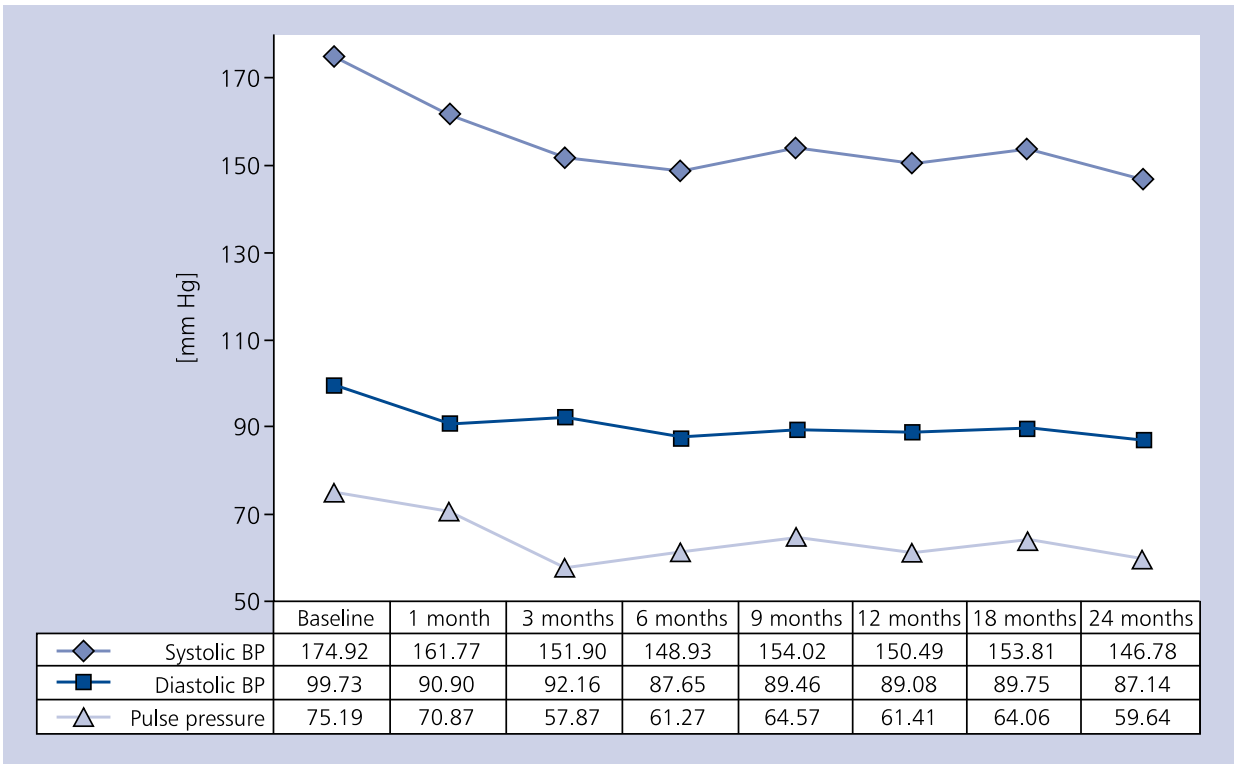

Figure 1. Mean systolic, diastolic blood pressure (BP), and pulse pressure at baseline and one, three, six, nine, 12, 18, and 24 months after the procedure. All results are statistically significantly $(p<0.05)$

arteries in each patient. No complications related to vascular access site or other adverse events like vascular, renal, or cardiovascular complications were noted. Visceral pain at the time of energy delivery was managed mostly with supplemental intravenous opioids. The one prolonged postoperative in-hospital stay was not related to the procedure, and all 32 patients were discharged home.

\section{One year after the procedure}

One year after the procedure, 30 patients showed up for follow-up visit. Three patients modified significantly the prescribed antihypertensive treatment and were excluded from the one year analysis. All other patients remained compliant with baseline pharmacotherapy.

The mean value of systolic BP for the 27 patients ranged from 111 to $203 \mathrm{~mm} \mathrm{Hg}$ (mean value $150.49 \mathrm{~mm} \mathrm{Hg}$ ) and was $24.42 \mathrm{~mm} \mathrm{Hg}$ lower than baseline, $(p<0.05)$. The mean value of diastolic BP for the 27 patients ranged from 63 to $117 \mathrm{~mm} \mathrm{Hg}$ (mean value $89.08 \mathrm{~mm} \mathrm{Hg}$ ) and was $10.65 \mathrm{~mm} \mathrm{Hg}$ lower than baseline before the ablation procedure, $\mathrm{p}<0.05$. The pulse pressure decreased to $61.41 \mathrm{~mm} \mathrm{Hg}$ (mean value) from baseline $75.19 \mathrm{~mm} \mathrm{Hg}, \mathrm{p}<0.05$. Systolic, and diastolic BP and pulse pressure were statistically significantly lower than at baseline. The highest mean BP reduction was: systolic $77.33 \mathrm{~mm} \mathrm{Hg}$, diastolic $45 \mathrm{~mm} \mathrm{Hg}(\mathrm{p}<0.05)$.

The mean values of heart rate ranged from 60 to $121 \mathrm{bpm}$ (mean value $77.36 \mathrm{bpm}$ ) during the one-year follow-up. The mean heart rate was $5.05 \mathrm{bpm}$ higher than that measured before the procedure (statistically not significant). No complications related to the ablation procedure nor adverse events were noted. The weight one year after the procedure ranged from 58 to $140 \mathrm{~kg}$ (mean value $90.52 \mathrm{~kg}$ ) and was not statistically different from the mean value before the procedure.

One year after the procedure in 30\% (eight patients) systolic BP was $\leq 140 \mathrm{~mm} \mathrm{Hg}$ and in 52\% (14 patients) diastolic $\mathrm{BP}$ was $\leq 90 \mathrm{~mm} \mathrm{Hg}$. Optimum BP value $\leq 140 / 90 \mathrm{~mm} \mathrm{Hg}$ was observed in $19 \%$ of all patients.

Additionally, all patients had a computed tomography (CT) scan performed to check for the renal artery lesions postoperatively. None of the patients who had a CT scan performed in 6-12 months of follow-up had significant lesions in renal arteries diagnosed. Two patients had up to $30 \%$ lesions in their renal arteries, but these lesions were already diagnosed during the preoperative angiography. No progress of any of these lesions was found in one-year follow-up.

\section{Two years after the procedure}

Two years after the procedure, 27 patients were seen in follow-up. All patients remained compliant with baseline pharmacotherapy. There were no reports of adverse clinical events related to the procedure or BP changes. Another five patients had substantial modification of medication or those not compliant to pharmacotherapy, so they were excluded from the study according to the protocol approved by the Ethical Committee.

The mean value of systolic BP for the 27 patients ranged from 117 to $192 \mathrm{~mm} \mathrm{Hg}$ (mean value $146.78 \mathrm{~mm} \mathrm{Hg}$ ) and was $28.14 \mathrm{~mm} \mathrm{Hg}$ lower than baseline, $\mathrm{p}<0.005$. The mean value of diastolic BP for the 27 patients ranged from 71 to $110 \mathrm{~mm} \mathrm{Hg}$ (mean value $87.14 \mathrm{~mm} \mathrm{Hg}$ ) and was $12.59 \mathrm{~mm} \mathrm{Hg}$ lower than baseline before the ablation procedure, $\mathrm{p}<0.005$. The pulse pressure decreased to $59.64 \mathrm{~mm} \mathrm{Hg}$ (mean value) from baseline $75.19 \mathrm{~mm} \mathrm{Hg}$ (Fig. 1), p < 0.05. Systolic, diastolic 
$\mathrm{BP}$, and pulse pressure were statistically significantly lower than at baseline. The highest mean BP reduction was: systolic $83 \mathrm{~mm} \mathrm{Hg}$, diastolic $49.67 \mathrm{~mm} \mathrm{Hg}$.

The mean values of heart rate ranged from 57 to $121 \mathrm{bpm}$ (mean value $82.96 \mathrm{bpm}$ ) during the two years of follow-up. The mean heart rate was $9.81 \mathrm{bpm}$ higher than that measured before the procedure. All these results were statistically significant $(p<0.005)$.

Two years after the procedure, in 30\% (eight patients) systolic BP was $\leq 140 \mathrm{~mm} \mathrm{Hg}$ and in $67 \%$ (18 patients) diastolic pressure was $\leq 90 \mathrm{~mm} \mathrm{Hg}$. Optimum BP values $\leq 140 / 90 \mathrm{~mm} \mathrm{Hg}$ were observed in $30 \%$ of all patients.

\section{DISCUSSION}

These long-term results are consistent with previous reports $[11,13]$. Radiofrequency renal nerve ablation is an effective treatment in reducing the level of BP in patients with arterial hypertension resistant to pharmacotherapy. In the carefully selected group of patients from Poland, systolic, diastolic, and pulse pressure were statistically significantly lower two years after the procedure. Also, the complete group of SYMPLICITY HTN-1 patients after two years follow-up showed that mean systolic and diastolic BP remained lowered $(p<0.001)$ [9].

Radiofrequency renal sympathetic denervation is a safe and effective treatment option for patients with drug-resistant hypertension. In the first clinical trials, the SIMPLICITY I (two-year follow-up) showed mean systolic BP reduction of $30 \mathrm{~mm} \mathrm{Hg}$ and diastolic BP of $14 \mathrm{~mm} \mathrm{Hg}$, and the SIMPLICITY II (one-year follow-up) showed mean systolic BP reduction of $28.1 \mathrm{~mm} \mathrm{Hg}$ and diastolic BP of $9.7 \mathrm{~mm} \mathrm{Hg}$ ( $p<0.001)$. After one year observation, both trials showed that durable $\mathrm{BP}$ reduction was present in $84 \%$ of patients $[9,10]$. It suggests, that radiofrequency renal ablation may reduce the total cardiovascular risk in patients with resistant hypertension according to the cardiovascular risk observed in non-resistant hypertension patients. The obvious BP lowering, especially the pulse pressure, can reflect future risk benefit for these patients; however, it is still too early to estimate the overall outcome of adverse events such as death, stroke, and myocardial infarction in long-term observation in this small study. Nonetheless, the patients enrolled had exhausted alternative therapy, and RN provided a calculable benefit in this cohort. The current reports do not report serious adverse events of the $\mathrm{RN}$, but few minor complications are noted: pseudoaneurysms in the access site, rapid onset hypotonia, urinary tract infections, paraesthesia, and pain, all self-limited complications [12] It should be emphasised that meta-analysis supports a $13 \%$ reduction of mortality for every $10 \mathrm{~mm} \mathrm{Hg}$ reduction of systolic $\mathrm{BP}$ [15]. In our group, the BP reduction was persistent in two years of follow-up.

To date, no long-term vascular or renal complications have been identified in large cohorts, or in our group of patients. Also, no new reports of renal failure, renal artery stenosis, syncope, or other vascular or cardiovascular adverse events were noted during two years of follow-up in the Polish sample.

The study, which was conducted to confirm the positive role of RN was called SYMPLICITY HTN-3; however, the results did not demonstrate sufficient effectiveness of this procedure in lowering BP [16]. The study showed no significant reduction in BP monitoring, both office measurement and 24-h ambulatory blood pressure monitoring (AMBP), in the population of patients who underwent RN compared with the control group (a placebo sham operated group, who received only arteriography of renal arteries). The results of SYMPLICITY HTN-3 were critically analysed, especially since the reverse results of the Global Simplicity Registry and the first meta-analysis of European studies were published [17]. All of this questioned denervation of the renal arteries as a step forward in the treatment of resistant hypertension. Also, our current analysis is at odds with the results of the SYMPLICITY HTN-3 study.

There are many hypotheses trying to explain the reasons for the discrepancy between study results. The simplest is that in SYMPLICITY HTN-3 patients improved the compliance both in terms of lifestyle changes and pharmacotherapy. However, it seems that the main reason for the negative results of SYMPLICITY HTN-3 was probably the different patient population including 25\% African Americans, who showed in subgroup analysis that they did not respond to renal denervation [18].

It is also believed that in some cases, the procedure was not effective because of poor catheter construction (the system has been changed now) and little experience of the operators. In all discussions, it is also emphasised that the crucial point of successful RN is proper patient selection and exclusion of patients who simply do not take hypertensive drugs [19]. Our patient population was very carefully selected from individuals with drug resistant hypertension confirmed for years. Also, all patients without proper compliance were excluded from the study.

Based on the HTN-3 study and other known studies on $\mathrm{RN}$, we can estimate that this method can be effective in a population of Caucasians, under the age of 60 years, without renal insufficiency, and with resistant hypertension treated obligatorily with four antihypertensive drugs, including aldosterone antagonist. In addition, renal denervation should be performed with more technologically advanced catheters than those used in the study HTN1-3 [19].

Additional positive effects of $\mathrm{RN}$ should support the positive role of this method in advanced patient care. Witkowski et al. [20] suggested that renal sympathetic denervation may be a potentially useful option for patients with comorbid resistant hypertension, glucose intolerance, and obstructive sleep apnoea. Schlaich et al. [21] performed renal denervation in obese and hypertense women with polycystic ovary syndrome 
(PCOS). In this study, renal denervation caused a reduction in both BP and insulin resistance, which are important therapeutic targets in PCOS patients. Improvement of glucose tolerance has also been confirmed by other authors [22, 23]. Renal denervation in patients with arterial hypertension also led to improvement of cardiac diastolic function, reduction of left ventricular mass [24], and reduction of augmentation index [25] in hypertension patients. Another group of patients in whom renal denervation can be a potential therapeutic option are haemodialysis patients with resistant or difficult to control hypertension. Performed studies showed that renal denervation significantly reduces $\mathrm{BP}$ in haemodialysis patients $[26,27]$. Unfortunately, in our group of patients, this kind of sub-analysis was not performed.

Another study performed on a Polish population is the Polish Renal Denervation registry [28]. In this study at 12-month follow-up the mean 24-h systolic BP change was $-8.3 \mathrm{~mm} \mathrm{Hg}$ at six months and $-4.6 \mathrm{~mm} \mathrm{Hg}$ at 12 months. This registry, similarly to our findings, demonstrated moderate BP decrease after RN; however, in both studies the selection of the patients was performed very carefully. Findings from both studies suggest that in the Polish patient population RN can be effective.

Renal sympathetic denervation, as a new method of hypertension treatment, deserves attention because there is enough data suggesting it can significantly lower BP in a carefully selected group of patients, and this effect is persistent in two years of follow-up.

\section{Limitations of the study}

This is a non-randomised, single-arm study with a relatively small patient sample size, which does not allow us to come to definitive conclusions for the general Polish population.

The study is a sub-analysis of two Polish cohorts of the SYMPLICITY I and SYMPLICITY II studies. Patients who were not compliant were excluded from the study, but we were not able check other patients' compliance. As was already mentioned, six applications per artery (according to the protocol) was probably not sufficient to reach perfect results of RN. Probably better catheter construction, which facilitates the electrode apposition and energy delivery into the arterial wall, will also eliminate the problems observed in unexperienced operators, associated with difficult anatomy of the artery, and decrease the total time of the procedure.

\section{CONCLUSIONS}

Renal sympathetic denervation is a safe and effective therapeutic treatment reducing the level of BP in patients with arterial hypertension resistant to pharmacotherapy. After two years of the procedure, no new or late complications or unexpected adverse events were noted in the Polish cohort of patients. The significant BP reduction after two years of follow-up was confirmed, with the BP below 140/90 $\mathrm{mm} \mathrm{Hg}$ in $30 \%$ of cases and diastolic BP below $90 \mathrm{~mm} \mathrm{Hg}$ in $67 \%$.
Conflict of interest and financial support: All the procedures were performed in the SYMPLICITY HTN-1 and SYMPLICITY HTN-2 studies, so the whole study was sponsored by Medtronic. The authors received a study fee for conducting the clinical trial.

\section{References}

1. Kearney PM, Whelton M, Reynolds K, et al. Global burden of hypertension: analysis of worldwide data. Lancet. 2005; 365(9455): 217-223, doi: 10.1016/S0140-6736(05)17741-1, indexed in Pubmed: 15652604

2. Go AS, Mozaffarian D, Roger VL, et al. Heart disease and stroke statistics--2013 update: a report from the American Heart Association. Circulation. 2013; 127(1): e6-e245, doi: 10.1161/CIR.0b013e31828124ad, indexed in Pubmed: 23239837

3. Turnbull F, Neal B, Ninomiya T, et al. Effects of different regimens to lower blood pressure on major cardiovascular events in older and younger adults: meta-analysis of randomised trials. BMJ. 2008; 336(7653): 1121-1123, doi: 10.1136/bmj.39548.738368. BE, indexed in Pubmed: 18480116.

4. Ong KL, Cheung BMY, Man YuB, et al. Prevalence, awareness, treatment, and control of hypertension among United States adults 1999-2004. Hypertension. 2007; 49(1): 69-75, doi: 10.1161/01.HYP.0000252676.46043.18, indexed in Pubmed: 17159087

5. Acelajado MC, Pisoni R, Dudenbostel T, et al. Refractory hypertension: definition, prevalence, and patient characteristics. J Clin Hypertens (Greenwich). 2012; 14(1): 7-12, doi: 10.1111/j.1751-7 176.2011.00556.x, indexed in Pubmed: 22235818.

6. Florczak E, Prejbisz A, Szwench-Pietrasz E, et al. Clinical characteristics of patients with resistant hypertension: the RESIST-POL study. J Hum Hypertens. 2013; 27(11): 678-685, doi: 10.1038/jhh.2013.32, indexed in Pubmed: 23698004.

7. Calhoun DA, Jones D, Textor S, et al. Resistant hypertension: diagnosis, evaluation, and treatment: a scientific statement from the American Heart Association Professional Education Committee of the Council for High Blood Pressure Research. Circulation. 2008; 117(25): e510-e526, doi: 10.1161/CIRCULATIONAHA.108.189141, indexed in Pubmed: 18574054.

8. Sarafidis PA, Bakris GL. Resistant hypertension: an overview of evaluation and treatment. J Am Coll Cardiol. 2008; 52(22): 1749-1757, doi: 10.1016/j.jacc.2008.08.036, indexed in Pubmed: 19022154

9. Krum H, Schlaich M, Whitbourn R, et al. Catheter-based renal sympathetic denervation for resistant hypertension: a multicentre safety and proof-of-principle cohort study. Lancet. 2009; 373(9671): 1275-1281, doi: 10.1016/S0140-6736(09)60566-3, indexed in Pubmed: 19332353.

10. Esler MD, Böhm M, Sievert H, et al. Catheter-based renal denervation for treatment of patients with treatment-resistant hypertension: 36 month results from the SYMPLICITY HTN-2 randomized clinical trial. Eur Heart J. 2014; 35(26): 1752-1759, doi: 10.1093/eurheartj/ehu209, indexed in Pubmed: 24898552.

11. Bartuś K, Sadowski J, Kapelak B, et al. Denervation (ablation) of nerve terminalis in renal arteries: early results of interventional treatment of arterial hypertension in Poland. Kardiol Pol. 2013; 71(2): 152-158, doi: 10.5603/KP.2013.0008, indexed in Pubmed: 23575708 .

12. Symplicity HTN-1 Investigators. Catheter-based renal sympathetic denervation for resistant hypertension: durability of blood pressure reduction out to 24 months. Hypertension. 2011; 57(5): 911-917, doi: 10.1161/HYPERTENSIONAHA.110.163014, indexed in Pubmed: 21403086. 
13. Bartuś K, Sadowski J, Kapelak B, et al. Denervation of nerve terminals in renal arteries: one-year follow-up of interventional treatment of arterial hypertension. Kardiol Pol. 2014; 72(5): 425-431, doi: 10.5603/KP.a2013.0357, indexed in Pubmed: 24408071.

14. Muntner P, Krousel-Wood M, Hyre AD, et al. Antihypertensive prescriptions for newly treated patients before and after the main antihypertensive and lipid-lowering treatment to prevent heart attack trial results and seventh report of the joint national committee on prevention, detection, evaluation, and treatment of high blood pressure guidelines. Hypertension. 2009; 53(4): 617-623, doi: 10.1161/HYPERTENSIONAHA.108.120154, indexed in Pubmed: 19221214.

15. Ettehad D, Emdin CA, Kiran A, et al. Blood pressure lowering for prevention of cardiovascular disease and death: a systematic review and meta-analysis. Lancet. 2016; 387(10022): 957-967, doi: 10.1016/S0140-6736(15)01225-8, indexed in Pubmed: 26724178.

16. Bhatt DL, Kandzari DE, O’Neill WW, et al. SYMPLICITY HTN-3 Investigators. A controlled trial of renal denervation for resistant hypertension. N Engl J Med. 2014; 370(15): 1393-1401, doi: 10.1056/NEJMoa1402670, indexed in Pubmed: 24678939.

17. Böhm M, Mahfoud F, Ukena C, et al. GSR Investigators. First report of the Global SYMPLICITY Registry on the effect of renal artery denervation in patients with uncontrolled hypertension. Hypertension. 2015; 65(4): 766-774, doi: 10.1161/HYPERTENSIONAHA.114.05010, indexed in Pubmed: 25691618.

18. Flack JM, Bhatt DL, Kandzari DE, et al. An analysis of the blood pressure and safety outcomes to renal denervation in African Americans and Non-African Americans in the SYMPLICITY HTN-3 trial. J Am Soc Hypertens. 2015; 9(10): 769-779, doi: 10.1016/j.jash.2015.08.001, indexed in Pubmed: 26362830.

19. Fengler K, Rommel KP, Okon T, et al. Renal sympathetic denervation in therapy resistant hypertension - pathophysiological aspects and predictors for treatment success. World J Cardiol. 2016; 8(8): 436-446, doi: 10.4330/wjc.v8.i8.436, indexed in Pubmed: 27621771.

20. Witkowski A, Prejbisz A, Florczak E, et al. Effects of renal sympathetic denervation on blood pressure, sleep apnea course, and glycemic control in patients with resistant hypertension and sleep apnea. Hypertension. 2011; 58(4): 559-565, doi: 10.1161/HYPERTENSIONAHA.111.173799, indexed in Pubmed: 21844482.
21. Schlaich MP, Straznicky N, Grima M, et al. Renal denervation: a potential new treatment modality for polycystic ovary syndrome? J Hypertens. 2011; 29(5): 991-996, doi: 10.1097/HJH.0b013e328344db3a, indexed in Pubmed: 21358414.

22. Schlaich MP, Sobotka PA, Krum H, et al. Renal sympathetic-nerve ablation for uncontrolled hypertension. N Engl J Med. 2009; 361(9): 932-934, doi: 10.1056/NEJMc0904179, indexed in Pubmed: 19710497.

23. Mahfoud F, Schlaich M, Kindermann I, et al. Effect of renal sympathetic denervation on glucose metabolism in patients with resistant hypertension: a pilot study. Circulation. 2011; 123(18): 1940-1946, doi: 10.1161/CIRCULATIONAHA.110.991869, indexed in Pubmed: 21518978.

24. Brandt MC, Mahfoud F, Reda S, et al. Renal sympathetic denervation reduces left ventricular hypertrophy and improves cardiac function in patients with resistant hypertension. J Am Coll Cardiol. 2012; 59(10): 901-909, doi: 10.1016/j.jacc.2011.11.034, indexed in Pubmed: 22381425.

25. Hering D, Lambert EA, Marusic P, et al. Renal nerve ablation reduces augmentation index in patients with resistant hypertension. J Hypertens. 2013; 31(9): 1893-1900, doi: 10.1097/HJH.0b013e3283622e58, indexed in Pubmed: 23697964.

26. Schlaich MP, Bart B, Hering D, et al. Feasibility of catheter-based renal nerve ablation and effects on sympathetic nerve activity and blood pressure in patients with end-stage renal disease. Int J Cardiol. 2013; 168(3): 2214-2220, doi: 10.1016/j.ijcard.2013.01.218, indexed in Pubmed: 23453868.

27. Di Daniele N, De Francesco M, Violo L, et al. Renal sympathetic nerve ablation for the treatment of difficult-to-control or refractory hypertension in a haemodialysis patient. Nephrol Dial Transplant. 2012; 27(4): 1689-1690, doi: 10.1093/ndt/gfs044, indexed in Pubmed: 22467751.

28. Kądziela J, Prejbisz A, Kostka-Jeziorny K, et al. Effects of renal sympathetic denervation on blood pressure and glycaemic control in patients with true resistant hypertension: results of Polish Renal Denervation Registry (RDN-POL Registry). Kardiol Pol. 2016; 74(9): 961-968, doi: 10.5603/KP.a2016.0058, indexed in Pubmed: 27160171.

Cite this article as: Bartuś K, Sadowski J, Kapelak B, et al. Renal artery sympathetic nerve radiofrequency denervation. Kardiol Pol. 2017; 75(9): 899-906, doi: 10.5603/KP.a2017.0100. 


\title{
Ablacja zakończeń nerwowych w tętnicy nerkowej prądem o wysokiej częstotliwości
}

\author{
Krzysztof Bartuś ${ }^{1}$, Jerzy Sadowski ${ }^{1}$, Bogusław Kapelak ${ }^{1}$, Radosław Litwinowicz ${ }^{1}$, Jakub Podolec ${ }^{2}$, \\ Magdalena Bartuś ${ }^{3}$, Artur Dziewierz ${ }^{4}$, Stanisław Bartuś ${ }^{4}$, Wojciech Zajdel${ }^{2}$, Dhanunjaya Lakkireddy 5 \\ 'Klinika Kardiochirurgii i Transplantologii, Uniwersytet Jagielloński, Szpital im. Jana Pawła II, Kraków \\ ${ }^{2}$ Klinika Kardiologii, Uniwersytet Jagielloński, Szpital im. Jana Pawła II, Kraków \\ ${ }^{3}$ Zakład Farmakologii Eksperymentalnej, Uniwersytet Jagielloński, Kraków \\ ${ }^{4}$ II Klinika Kardiologii, Uniwersytet Jagielloński, Szpital Uniwersytecki, Kraków \\ ${ }^{5}$ The University of Cansas, Cansas City, Stany Zjednoczone
}

\section{Streszczenie}

Wstęp: Nadciśnienie tętnicze jest jedną z najbardziej powszechnych chorób przewlekłych w krajach zachodnich i dotyczy więcej niż 25\% dorosłej populacji.

Cel: Celem pracy była ocena zmian ciśnienia tętniczego (BP) u pacjentów z nadciśnieniem tętniczym po ablacji zakończeń nerwowych w tętnicach nerkowych z zastosowaniem prądu o wysokiej częstotliwości w 24-miesięcznej obserwacji.

Metody: Trzydziestu dwóch pacjentów z rozpoznanym nadciśnieniem opornym (20 mężczyzn i 12 kobiet) poddano przezskórnej denerwacji zakończeń nerwowych w ścianie tętnic nerkowych. Średnia wartość ciśnienia krwi przed ablacją wynosiła [mm Hg]: 174,92 (skurczowe), 99,73 (rozkurczowe), a ciśnienie tętna - 75,19. Po 24 miesiącach obserwacji stwierdzono zmniejszenie wartości ciśnienia tętniczego [mm Hg]: skurczowe - 146,78; rozkurczowe — 87,14, ciśnienie tętna — 59,64. Wyniki: Wszystkie wyniki były statystycznie znamienne. U 30\% pacjentów zanotowano wartość skurczowego BP $\leq 140 \mathrm{~mm} \mathrm{Hg}$, u $67 \%$ osób rozkurczowe BP wynosiło $\leq 90 \mathrm{~mm} \mathrm{Hg}$, natomiast optymalne wartości ciśnienia krwi ( $\leq 140 / 90 \mathrm{~mm} \mathrm{Hg}$ ) stwierdzono u 30\% pacjentów po 24 miesiącach od ablacji tętnic nerkowych.

Wnioski: W grupie badanych chorych przezskórna ablacja tętnicy nerkowej skutecznie obniżyła skurczowe i rozkurczowe BP oraz ciśnienia tętna. Nie stwierdzono istotnych zdarzeń niepożądanych w ciągu 24-miesięcznej obserwacji. Wyniki badań polskiej grupy pacjentów nie odbiegają w żaden sposób od wyników uzyskanymi w badaniach SIMPLICITY I i II.

Słowa kluczowe: nadciśnienie tętnicze, ablacja tętnic nerkowych

Kardiol Pol 2017; 75, 9: 899-906 